\title{
Effects of Winter Harvesting and Salinity on the Structure of Regrowing Reed Stands
}

\author{
Mingyao Huang, Qiang Sheng, Jihua Wu, Xiaoyun Pan* \\ Coastal Ecosystems Research Station of Yangtze River Estuary, Ministry of Education Key Laboratory for \\ Biodiversity Science and Ecological Engineering, Institute of Biodiversity Science, Fudan University, Shanghai, \\ China \\ Email: *xypan@fudan.edu.cn
}

Received 8 August 2014; revised 15 September 2014; accepted 19 October 2014

Copyright (C) 2014 by authors and Scientific Research Publishing Inc.

This work is licensed under the Creative Commons Attribution International License (CC BY). http://creativecommons.org/licenses/by/4.0/

(c) (i) Open Access

\begin{abstract}
Harvest and salinity are two important factors of the growth of common reed (Phragmites australis). We here examined the different impact of winter harvest treatment on the Phragmites australis between high and low salinity (mean soil electrical conductivity is $7.87 \mathrm{~ms} / \mathrm{cm}$ and $0.91 \mathrm{~ms} / \mathrm{cm}$ ) areas in Dongtan wetland of Yangtze River estuary, China. We measured phenology, Shoot density, stem diameter and height, biomass (total, aboveground and belowground biomass) and spike weight. At high salinity areas, harvest significantly inhibited the individual growth of stem height yet enhanced ramet density, and consequently led to an insignificant change in aboveground biomass. The belowground parts of reed were significantly inhibited. The root shoot ratio and the proportion of asexual reproduction decreased significantly. At low salinity areas, however, winter harvest generally has no significant influence on reed growth. Our results suggest that the winter harvest management may cause a decline of reed populations in the long term under condition of high salinity; however winter harvesting can be suggested as a proper management for sustainable utilization of reed communities at low salinity areas.
\end{abstract}

\section{Keywords}

Management, Biomass, Phenology, Allometry

\section{Introduction}

Common reed Phragmites austrilis (Gramimeae), a cosmopolitan species [1] [2] has a great ecological and economic value [3]-[5]. Reed community serves as an important habitat for plants and animals, and live reeds are

\footnotetext{
*Corresponding author.
} 
used for stabilizing river and canal banks. Reeds are grazed by livestock and harvested for thatching material, fences, coarse mats, baskets, etc. Harvesting as a management of reed community has widely been applied all over the world and plays an important role in maintaining the sustainability of reed community [3]-[5]. However, researches on the effect of harvesting on the regrowth of reed are not consistent. Valkama et al. [5] applied metaanalysis to report that harvesting reduced reed stem height and increased stem density, while not changing aboveground biomass. However, Hasson and Graneli [6] found that winter harvesting caused an almost doubling of shoot production. Asaeda et al. [7] showed that the regrowth of the aboveground biomass declined significantly due to cutting in June but not differed due to cutting in July. Asaeda et al. [7] found that the shoot biomass of June-harvested tended to be lower than July-harvested and no harvest control.

Salinity is an important factor for the growth and distribution of reeds. Rhizome-grown reeds showed an optimum relative growth rate at 5\%o salinity [8]. It is suggested that the relative growth rate of reed was highest at salinity level between $0 \%$ - 1.5\% [9] and declined rapidly with increasing salinity [10]. Reed shows low mortality at salinity level up to $15 \%$, higher mortality at $22.5 \%$, and all plants died at salinity of $35 \%$ o [8] [9]. Asaeda $e t$ al. [11] found that reed growth was severely retarded by cutting combined with salinity treatment in experimental conditions.

In order to explore an effective management of reed population under the habitats with different salinity levels, we studied the effects of winter harvesting and salinity on the following traits of regrowing reed populations: 1) Phenology; 2) shoot density; 3) biomass and allocation; 4) reproduction; and 5) allometry relationship between stem diameter and height.

\section{Material and Methods}

\subsection{Study Site}

Field studies were carried out at the Chongming Dongtan National Nature Reserve $\left(31^{\circ} 25^{\prime}-31^{\circ} 38^{\prime} \mathrm{N}, 121^{\circ} 50^{\prime}\right.$ $122^{\circ} 05^{\prime} \mathrm{E}$ ) on Chongming Island in the Yangtze River estuary, Shanghai, China. The island has a northern subtropical monsoon climate with annual average temperature of $15.3^{\circ} \mathrm{C}$ and annual rainfall of $1022 \mathrm{~mm}$ [12]. The total area of conservation area is 24,600 ha, and the area of reed population is about 451.8 ha [13]. The Yangtze River is divided into the South and North Branch by Chongming Island (Figure 1). Saltwater spilling over from the North Branch runs into the South Branch during the dry season [14], which caused the soil salinity in North of Chongming Island is significantly higher than in South of Chongming Island [15].

Considering these differences in soil salinity, we chose two sites: one site in North of Chongming Island with higher salinity (HS) area (mean soil electrical conductivity is $7.87 \mathrm{~ms} / \mathrm{cm}$ ), and the other one in South of Changming Island with lower salinity (LS) area (mean soil electrical conductivity is $0.91 \mathrm{~ms} / \mathrm{cm}$ ) (Figure 1). Reeds were harvested every year in winter at these sites. Winter harvesting $(\mathrm{H})$ and unharvesting (UH) treat-

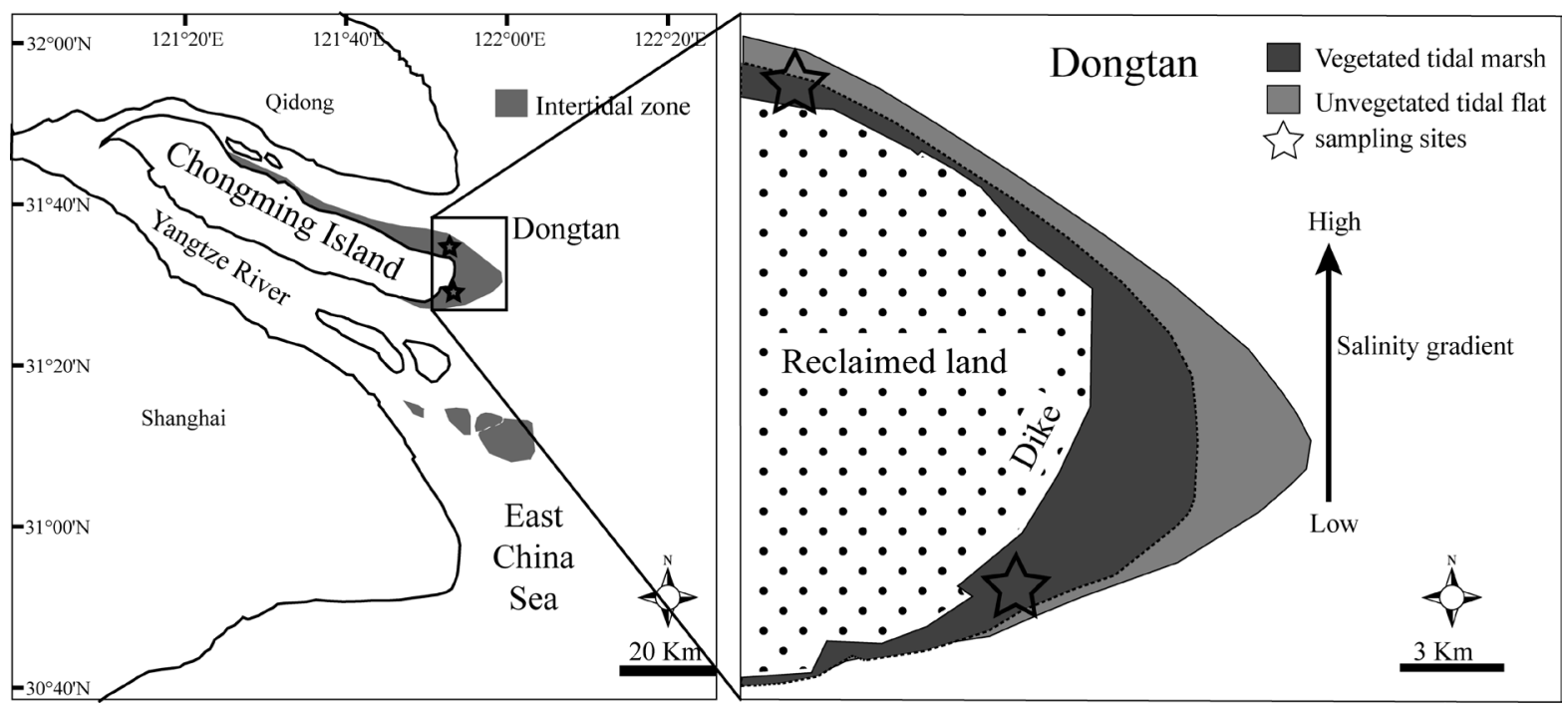

Figure 1. The sketch map of study sites. 
ments were randomly assigned in the two study areas. Every treatment had four replicate plots (20 $\mathrm{m} \times 20 \mathrm{~m})$. Twelve replicate quadrats $(50 \mathrm{~cm} \times 50 \mathrm{~cm})$ were established in each plot on November 2011. The quadrats were spaced $1 \mathrm{~m}$ apart, and positioned $1 \mathrm{~m}$ from the edge of the plot to limit edge effects. Reeds were harvested by using a hand-held trimmer on November 2011. Stubble height was about 5 - $10 \mathrm{~cm}$.

\subsection{Sample Collection}

Phenological observation Three $50 \mathrm{~cm} \times 50 \mathrm{~cm}$ quadrats were chosen in each plot, to record the phenological phase during a reed growing season. The phenological observations covered 7 phenophases (germination, leafing, elongation, booting, heading, fructescence and withering) (Figure 2) [16] [17]. When 10\% of the plants reached the growth period, we considered initiation of phenophase [16] [17].

Shoot density Three $50 \mathrm{~cm} \times 50 \mathrm{~cm}$ quadrats were used for repeated recordings of reed population density in each plot.

Stem diameter and height Three $50 \mathrm{~cm} \times 50 \mathrm{~cm}$ quadrats were used for measured stem diameter and height in each plot. 10 plants were randomly selected and collected in each quadrat on 15 May 2012.

Biomass Three $50 \mathrm{~cm} \times 50 \mathrm{~cm}$ quadrats were used for measuring spike weight in each plot. Five spikes were randomly selected and collected in each quadrat on 4 November 2012. At fructescence, the spike of each shoot was isolated in a nylon bag (100 mesh). At wilting period, spike together with bag were collected and dried at $60^{\circ} \mathrm{C}$ to constant weight in a drying chamber and weighed.

Biomass which only kept all live parts and removed all the dead parts was collected on 15 September 2012 (the late vegetative growth, before reproductive growth). Aboveground biomass was taken from the area of 50 $\mathrm{cm} \times 50 \mathrm{~cm}$ at per plot. Belowground biomass was taken using a core-sampling method at the middle of the 50 $\mathrm{cm} \times 50 \mathrm{~cm}$ quadrats where the aboveground biomass was collected. The soil cores were $15 \mathrm{~cm}$ in diameter and $60 \mathrm{~cm}$ in length. The belowground biomass columns were divided into a 0 - $20 \mathrm{~cm}$ topsoil layer, $20-40 \mathrm{~cm}$ deep soil layer and 40 - $60 \mathrm{~cm}$ deeper soil layer for comparing the differences of belowground biomass in different depth of soil. All the samples were washed in clean water by sieve with a mesh size of $0.45 \mathrm{~mm}$. Live and dead matter were distinguished by color and texture [18] [19]. Live rhizomes and roots were pearl white, translucent, and fairly rigid. Dead matter was duller gray and flaccid. All biomass were dried at $60^{\circ} \mathrm{C}$ to constant weight in a drying chamber and weighed.

Root shoot ratio = belowground biomass/aboveground biomass .

Reproduction allocation $=($ individual spike biomass/individual plant biomass $) \times 100 \%$.

\subsection{Statistical Analyses}

We used two-way ANOVA to evaluate the effects of salinity and harvest treatment on biomass, root shoot ratio, stem height and diameter, spike weight. Data were log-transformed to homogenize variances. Tukey’s HSD was used for comparing between harvest treatments. Allometric growth relationship between stem height and stem diameter was described by the classic allometric equation $\mathrm{y}=\beta \mathrm{x}^{\alpha}$. Data was log-transformed that the allometric equation became a linear equation $\lg =\lg \beta+\alpha \lg x$.

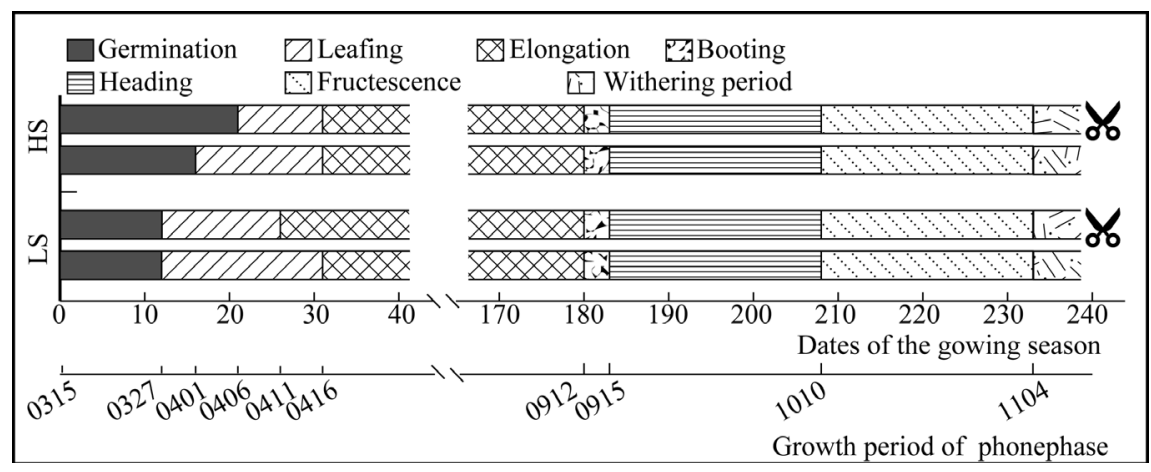

Figure 2. Phenophase spectrum of Phragmites australis at high and low salinity area after winter harvesting. March 15, 2012 was the start of growing season which noted as 0 . Scissor symbol denote harvest treatment at high and low salinity area. 


\section{Result}

\subsection{Phenology and Population Density}

Winter harvesting affected the phenology differently in the context of salinities (Figure 2). At high salinity, germination stage increased by 5 days; leafing stage delayed by 5 days and shortened by 5 days. At low salinity, leafing stage shortened by 5 days and elongation started 5 days earlier. Both harvesting and salinity had no effects on phenology after elongation stage.

The dynamic of shoot density showed a unimodal pattern. The peak value appeared at leafing stage (Figure 3). At high salinity, shoot density was higher in harvested sample than in control between germination and elongation stage; and on the contrary after elongation stage. At low salinity, shoot density was higher in harvested sample than in control during the whole growing season.

\subsection{Biomass Allocation and Reproduction}

Effects of winter harvest on biomass accumulation and allocation significantly differed between low and high salinity. Total biomass significantly decreased by harvesting $(-34.7 \%, \mathrm{P}<0.05)$ at high salinity, but did not differ significantly $(\mathrm{P}>0.05)$ at low salinity (Figure 4).

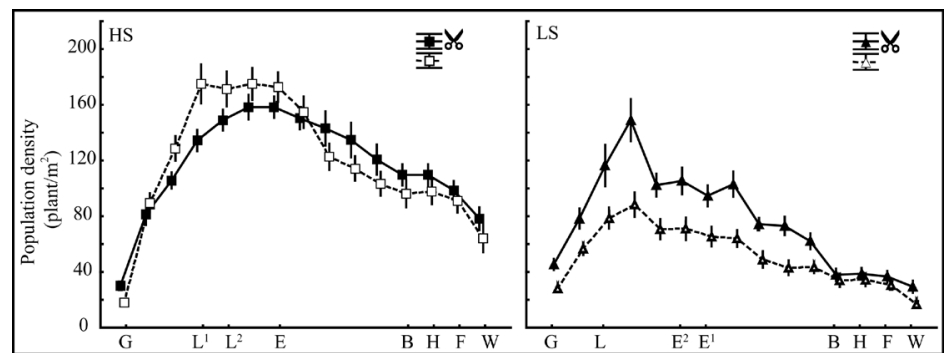

Figure 3. The dynamic of population density of Phragmites australis at high and low salinity aress. Bars represent standard errors of mean data $(n=12)$. G: Germination; L: Leafing; E: Elongation; B: Booting; H: Heading; F: Fructescence; W: Withering. Number 1 and 2 denote harvest and un-harvest treatment respectively. Scissor symbol denote harvest treatment (black symbols), white symbol denote un-harvest treatment.

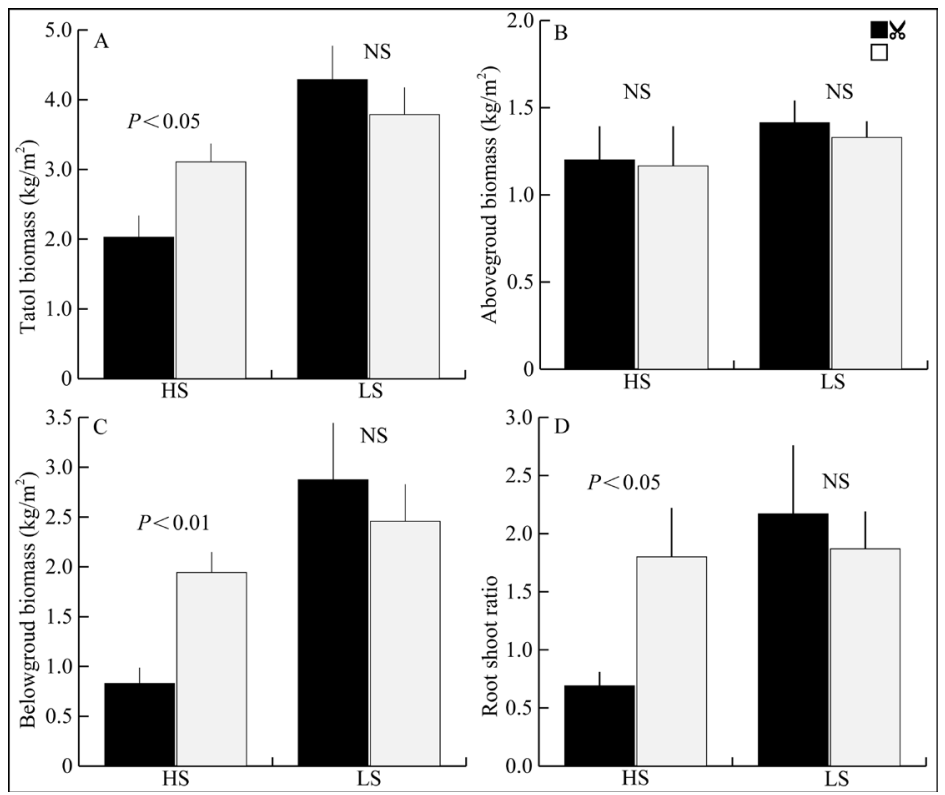

Figure 4. Total biomass (A), aboveground biomass (B), belowground biomass (C) and root shot ratio (D) of Phragmites australis at high and low salinity area after winter harvesting. Significant and insignificant effects are indicated, NS: Not significant. Scissor symbol denote harvest treatment (black symbol), white symbol denote un-harvest treatment. Bars represent standard errors of mean data $(n=4)$. 
The aboveground biomass did not differ significantly between harvest and un-harvest treatment regardless of salinity. Belowground biomass significantly decreased by harvesting $(-57.3 \%, \mathrm{P}<0.01)$ at high salinity. Belowground biomass decreased significantly in both the layer of $0-20 \mathrm{~cm}(-70.4 \%)$ and $20-40 \mathrm{~cm}(-85.0 \%)$, but was not affected by harvesting in the layer of $40-60 \mathrm{~cm}$ at high salinity area. At high salinity areas, root shoot ratio was significantly reduced by harvesting (-63.5\%). At low salinity, however, all of the parameters were not affected by harvesting as shown in Figure 4 and Figure 5.

Harvesting had no significant effects on spike weight and reproduction allocation regardless of salinity (Figure 6).

\subsection{Allometric Relationship of Stem Height and Diameter}

Phragmites australis plants showed simple allometric relationships between height and diameter at all treatments. The slope of allometric relationship was significantly lower than 1 (95\% confidence interval [CI] 0.47 0.76 and $0.56-0.80$ at high and low salinity, respectively) at un-harvest treatment, but not significantly different from 1 (95\% CI $0.64-1.05$ and 0.74 - 1.03 respectively) at harvest treatment (Figure 7).

\section{Discussion}

Our result demonstrated that the effects of winter harvest on Phragmites australis phenology were different at different salinity areas. Winter harvest placed effects on lengthening germination stage and shortening leafing stage at high salinity areas, while shortening leafing stage at low salinity areas.

Furthermore, we demonstrated that the effects of winter harvest on biomass accumulation and allocation de-

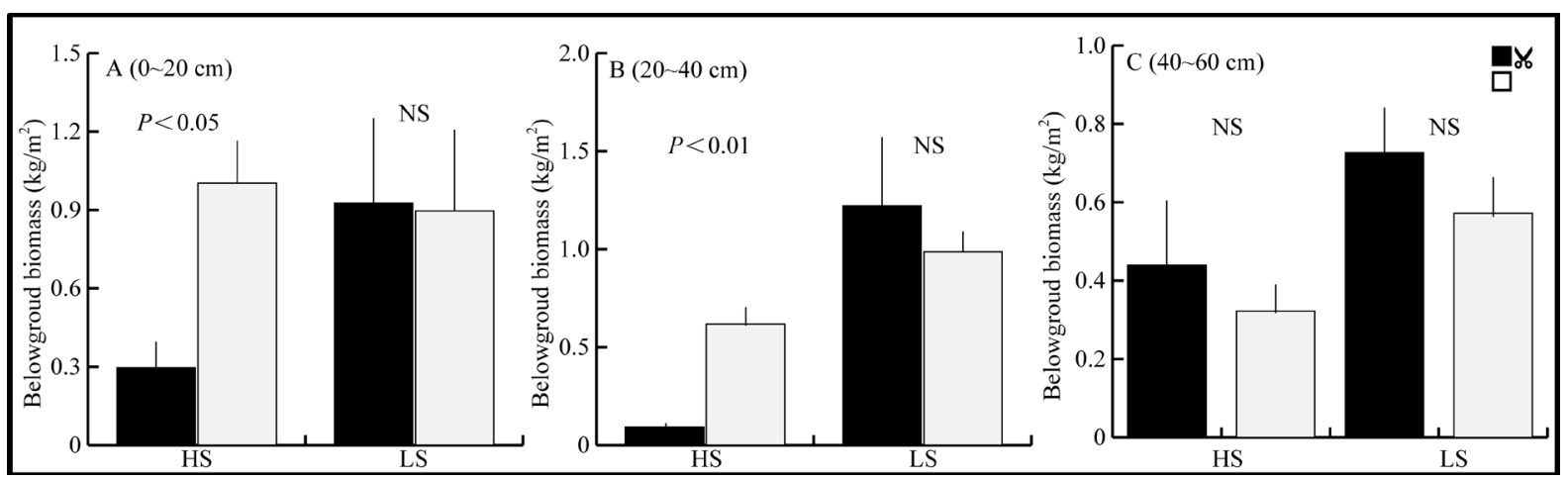

Figure 5. Belowground biomass of Phragmites australis at different layers at high and low salinity area after winter harvest. (A) 0 - $20 \mathrm{~cm}$ soil depth; (B) 20 - $40 \mathrm{~cm}$ soil depth; (C) 40 - $60 \mathrm{~cm}$ soil depth. Significant and insignificant effects are indicated. NS: Not significant. Scissor symbol denote harvest treatment (black symbol), white symbol denote un-harvest treatment. Bars represent standard errors of mean data $(n=4)$.

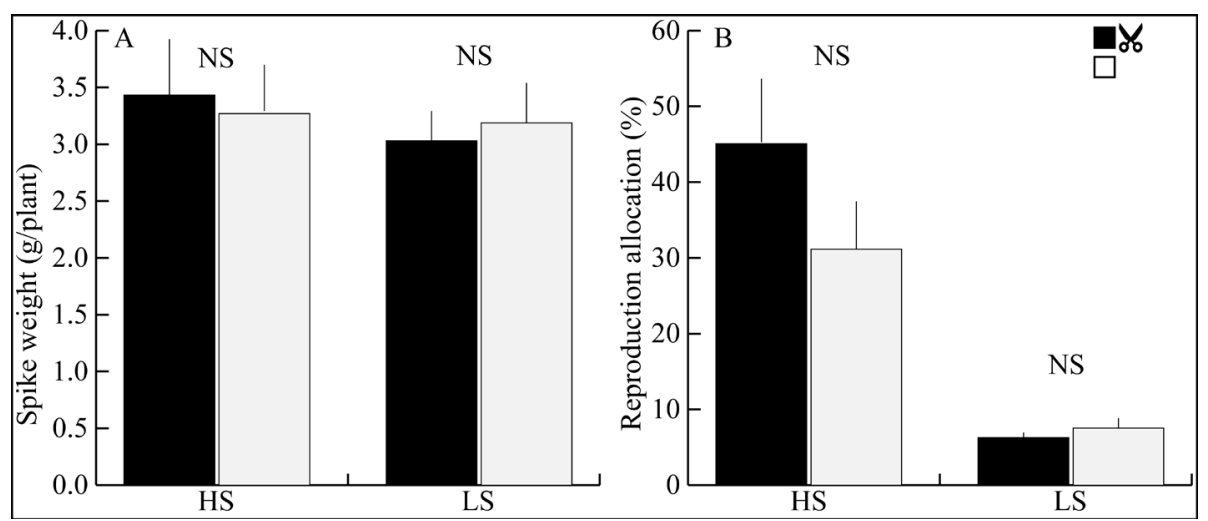

Figure 6. Spike weight (A) and reproductive allocation (B) of Phragmites australis at high and low salinity area after winter harvest. Significant and insignificant effects are indicated. NS: Not significant. Scissor symbol denote harvest treatment (black symbol), white symbol denote un-harvest treatment. Bars represent standard errors of mean data $(n=60)$. 


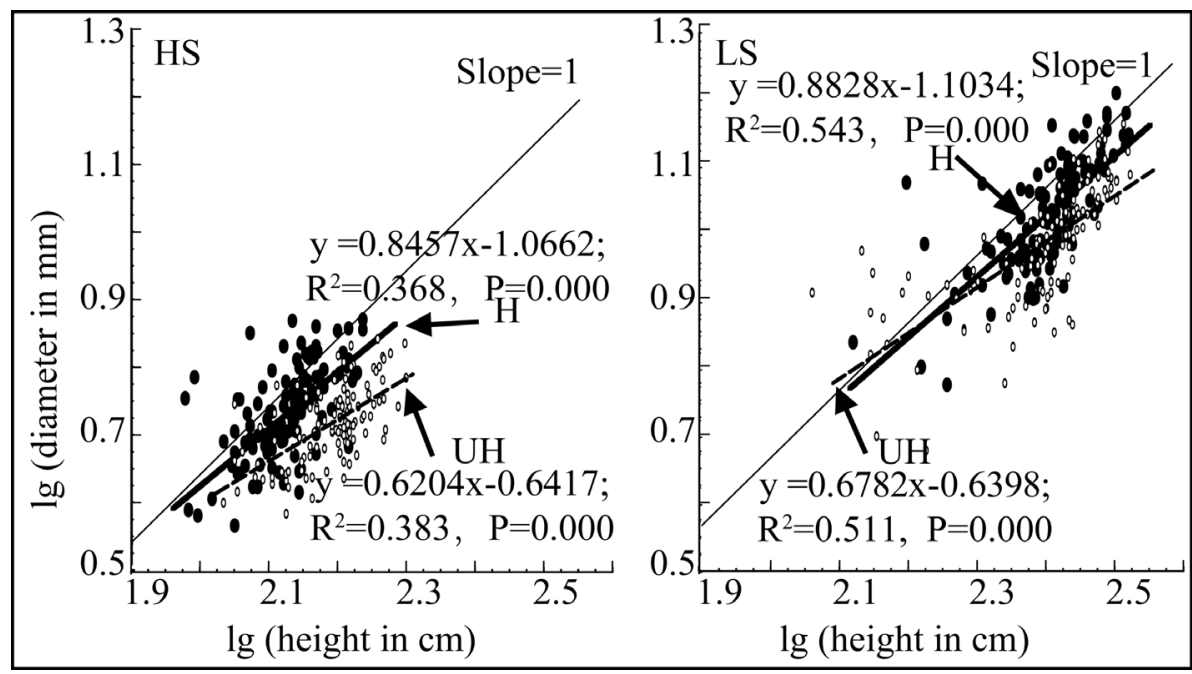

Figure 7. Allometry relationships on the logarithm of height of Phragmites australis and logarithm of Stem diameter of Phragmites australis at high and low salinity area after winter harvesting in May. Letter (H, UH) denote harvesting treatment and un-harvesting treatment.

pend on soil salinities. Total biomass, belowground biomass and root shoot ratio were reduced significantly by winter harvest at high salinity areas, but not at low salinity areas. A negative response to salt stress is typically demonstrated where reduced growth occurs as a result of energy diversion from meristematic new growth to maintenance of osmotic balance [20] [21]. High concentrations of salt in the root zone considerably reduced water uptake [22]. When combined the effect of salinity and winter harvest, growth of reed would restrict further [11].

We also found that winter harvest did not affect the aboveground biomass of reed plants, which is similar with previous studies [5] [23].

Analysis of belowground biomass at different soil depth revealed that effect of harvest on belowground biomass was mainly at topsoil roots of high salinity areas. Biomass in both the layer of soil depth $0-20 \mathrm{~cm}$ and 20 $40 \mathrm{~cm}$ significantly decreased at high salinity areas. This was because the activity of reed upper roots had a closer relationship with the growth [24].

High root shoot ratio indicated that more resource allocations were used for shoot development to benefit reed survival competition after harvest treatment at high salinity area. Yang et al. [24] found when reed grew a given period, photosynthetic was translocated to rhizomes. Belowground biomass reduced by winter harvest at high salinity areas, which indicated reed allocated more resource to shoots, and less matter stored at belowground biomass under the combined stresses of harvest and high salinity.

Here we found that spike weight and reproduction allocation was not affected by high or low salinity areas. This result was inconsistent with study of Asaeda et al. [11]. They found that no panicles were formed in saltwater-treated cut plants, and the number of panicles reduced in fresh-water-treated cut plants.

Observation of population density demonstrated effects of harvest and salinity on the belowground biomass well. (Our data showed that) population density decreased first (pre-elongation stage) and then increased (postelongation stage) by harvest treatment at high salinity areas. However, population density was higher at harvest treatment than un-harvest treatment all growing season at low salinity areas. There are abundant energy-rich compounds that provide energy for growth and development of reed rhizome buds such as carbohydrate and protein and so on in reed rhizome [7] [25].

The relationship between stem height and diameter was altered by harvest treatment no matter at high or low salinity areas. The slope of relationship between stem height and diameter was less than 1 , which indicated that height grew more rapidly than the diameter [26]. However the results of 95\% CI showed that harvest treatment changed the relationship from allometric growth to isometric growth. Previous studies [27] [28] found that plant allometry is altered by competition. Relationships between plant height and stem diameter usually was linear (simple allometry) in uncrowned stands, but curvilinear or discontinuous in crowded stands. In our study, population density was higher at harvest areas than un-harvest areas in May (elongation stage). Population density 
can alter the growth and form of plants [27] [29] through modifying the amount of resources available to individuals within a population.

However our result was inconsistent with study of Güsewell [30]. He found that allometric relationships between shoot length and diameter did not differ between cut and control plots. The difference may be due to the reason that the number of shoots per unit area was reduced in the re-growth after mowing in his study.

In conclusion, the effects of winter harvest management on reed growth varied under different salinity conditions. We suggest that winter harvest management would probably cause a decline of reed populations in the long term under high salinity condition; however it can also be as a proper management mode for sustainable utilization of reed communities at low salinity areas.

\section{Acknowledgements}

We thank Tianjiang Chu and Sikai Wang for their help in field sampling. This study was financially supported by the National Natural Science Foundation of China (31370433), the National Science and Technology Ministry (2013CB430404), and Science and Technology Department of Shanghai (12231204700, 13231203503).

\section{References}

[1] Clayton, W.D. (1967) Studies in the Gramineae, XIV. Kew Bulletin, 21,113-117.

[2] Clevering, O.A. and Lissner, J. (1999) Taxonomy, Chromosome Numbers, Clonal Diversity and Population Dynamics of Phragmites australis. Aquatic Botany, 64, 185-208. http://dx.doi.org/10.1016/S0304-3770(99)00059-5

[3] Haslam, S.M. (1972) Phragmites communis Trin.: Biological Flora of the British Isles. Journal of Ecology, 60, 585610.

[4] Doody (2008) Saltmarsh Conservation, Management and Restoration. Coastal Systems and Continental Margins, 12. Springer, Brampton.

[5] Valkama, E., Lyytinen, S. and Koricheva, J. (2008) The Impact of Reed Management on Wildlife, a Meta-Analytical Review of European Studies. Biological Conservation, 141, 364-374. http://dx.doi.org/10.1016/j.biocon.2007.11.006

[6] Hansson, L.A. and Graneli, W. (1984) Effects of Winter Harvest on Water and Sediment Chemistry in a Stand of Reed (Phragmites australis). Hydrobiologia, 112, 131-136. http://dx.doi.org/10.1007/BF00006917

[7] Asaeda, T., Rajapakse, L., Manatunge, J. and Sahara, N. (2006) The Effect of Summer Harvesting of Phragmites australis on Growth Characteristics and Rhizome Resource Storage. Hydrobiologia, 553, 327-335. http://dx.doi.org/10.1007/s10750-005-1157-6

[8] Lissner, J. and Schierup, H.H. (1997) Effects of Salinity on the Growth of Phragmites australis. Aquatic Botany, 55, 247-260. http://dx.doi.org/10.1016/S0304-3770(96)01085-6

[9] Hartzendorf, T. and Rolletschek, H. (2001) Effects of NaCl-Salinity on Amino Acid and Carbohydrate Contents of Phragmites australis. Aquatic Botany, 69, 195-208. http://dx.doi.org/10.1016/S0304-3770(01)00138-3

[10] Wang, Q., Wang, C.H., Zhao, B., et al. (2006) Effects of Growing Conditions on the Growth of and Interactions between Salt Marsh Plants, Implications for Invasibility of Habitats. Biological Invasions, 8, 1547-1560. http://dx.doi.org/10.1007/s10530-005-5846-x

[11] Asaeda, T., Manatunge, J., Fujino, T. and Sovira, D. (2003) Effects of Salinity and Cutting on the Development of Phragmites australis. Wetlands Ecology and Management, 11, 127-140. http://dx.doi.org/10.1023/A:1024289025415

[12] Xu, H.F. and Zhao, Y.L. (2005) Comprehensive Surveys in Chongmig Dongtan Nature Reserve for Migratory Birds, Shanghai. Chinese Forestry, Beijing. (in Chinese)

[13] Huang, H.M., Zhang, L.Q. and Yuan, L. (2007) The Spatio-Temporal Dynamics of Salt Marsh Vegetation for Chongming Dongtan National Nature Reserve, Shanghai. Acta Ecologica Sinica, 27, 4166-4172. (in Chinese with English Abstract)

[14] Wu, H., Zhu, J.R., Chen, B.R. and Chen, Y.Z. (2006) Quantitative Relationship of Runoff and Tide to Saltwater Spilling over from the North Branch in the Changjiang Estuary: A Numerical Study. Estuarine, Coastal and Shelf Science, 69, 125-132. http://dx.doi.org/10.1016/j.ecss.2006.04.009

[15] Yang, C.M., Wang, M.M., Cai, W.J. and Li, J.H. (2012) Bensulfuron-Methyl Biodegradation and Microbial Parameters in a Riparian Soil as Affected by Simulated Saltwater Incursion. Clean-Soil, Air, Water, 40, 348-355. http://dx.doi.org/10.1002/clen.201000540

[16] Zhu, K.Z. and Wan, M.W. (1973) Phenology. Science Press, Beijing. (in Chinese)

[17] Wan, M.W. and Liu, X.Z. (1979) Method of Phenology Observation of China. Science Press, Beijing. (in Chinese) 
[18] Veliela, I., Teal, J.M. and Persson, N.Y. (1976) Production and Dynamics of Experimentally Enriched Salt Marsh Vegetation: Belowground Biomass. Limnology and Oceanography, 21, 245-252. http://dx.doi.org/10.4319/lo.1976.21.2.0245

[19] Liao, C.Z., Luo, Y.Q., Jiang, L.F., Zhou, X.H., Wu, X.W., Fang, C.M., Chen, J.K. and Li, B. (2007) Invasion of Spartina alterniflora Enhanced Ecosystem Carbon and Nitrogen Stocks in the Yangtze Estuary, China. Ecosystems, 10, 1351-1361. http://dx.doi.org/10.1007/s10021-007-9103-2

[20] Hellings, S.E. and Gallagher, J.L. (1992) The Effects of Salinity and Flooding on Phragmites australis. Journal of Applied Ecology, 29, 41-49. http://dx.doi.org/10.2307/2404345

[21] Hurry, C.R., James, E.A. and Thompson, R.M. (2013) Connectivity, Genetic Structure and Stress Response of Phragmites australis, Issus for Restoration in a Salinising Wetland System. Aquatic Botany, 104, 138-146. http://dx.doi.org/10.1016/j.aquabot.2012.08.001

[22] Munns, R. and Tester, M. (2008) Mechanisms of Salinity Tolerance. Annual Review of Plant Biology, Palo Alto, 59, 651-681.

[23] Björndahl, G. (1985) Influence of Winter Harvest on Stand Structure and Biomass Production of the Common Reed, Phragmites australis (Cav.) Trin. ex Steud. In Lake Takern, Southern Sweden. Biomass, 7, 303-319. http://dx.doi.org/10.1016/0144-4565(85)90069-1

[24] Yang, Y.F., Wei, C.Y., Zhang, B.T. and Liu, B. (2005) Dynamic of Bud Flow and Bud Bank of Phragmites communis Population in Dry Land Habitat of Alkalinized Meadow in the Songnen Plains of China. Chinese Journal of Applied Ecology, 16, 854-858. (in Chinese with English Abstract)

[25] League, M.T., Colbert, E.P., Seliskar, D.M. and Gallagher, J.L. (2006) Rhizome Growth Dynamics of Native and Exotic Haplotypes of Phragmites australis (Common Reed). Estuaries and Coasts, 29, 269-276. http://dx.doi.org/10.1007/BF02781995

[26] Huxley, J.S. (1932) Problems of Relative Grouth. Methuen and Co. Ltd., London.

[27] Weiner, J. and Thomas, S.C. (1992) Competition and Allometry in Three Species of Annual Plants. Ecology, 73, 648656. http://dx.doi.org/10.2307/1940771

[28] Weiner, J. and Fishman, L. (1994) Competition and Allometry in Kochia scoparia. Annals of Botany, 73, $263-271$. http://dx.doi.org/10.1006/anbo.1994.1031

[29] Li, L., Weiner, J., Zhou, D.W., Huang, Y.X. and Sheng, L.X. (2013) Initial Density Affects Biomass-Density and Allometric Relationships in Self-Thinning Populations of Fagopyrum esculentum. Journal of Ecology, 101, 475-483. http://dx.doi.org/10.1111/1365-2745.12039

[30] Güsewell, S. (2003) Management of Phragmites austrlis in Swiss Fen Meadows by Mowing in Early Summer. Wetlands Ecology and Management, 11, 433-445. http://dx.doi.org/10.1023/B:WETL.0000007197.85070.58 
Scientific Research Publishing (SCIRP) is one of the largest Open Access journal publishers. It is currently publishing more than 200 open access, online, peer-reviewed journals covering a wide range of academic disciplines. SCIRP serves the worldwide academic communities and contributes to the progress and application of science with its publication.

Other selected journals from SCIRP are listed as below. Submit your manuscript to us via either submit@scirp.org or Online Submission Portal.
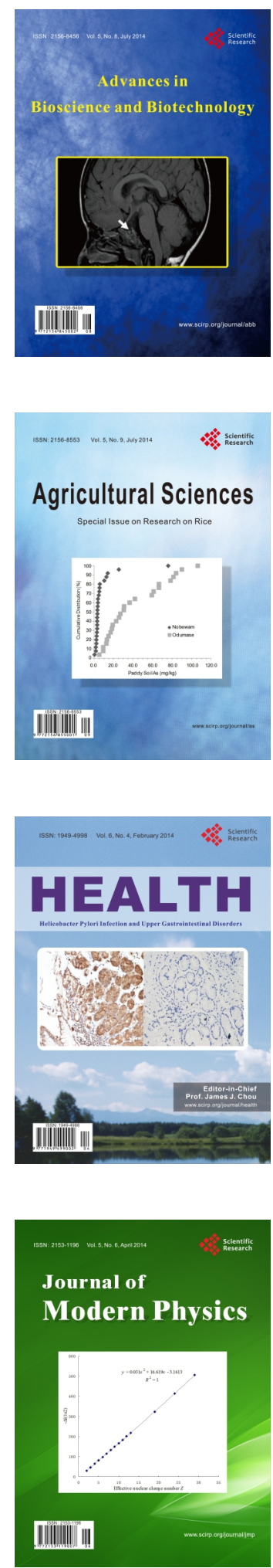
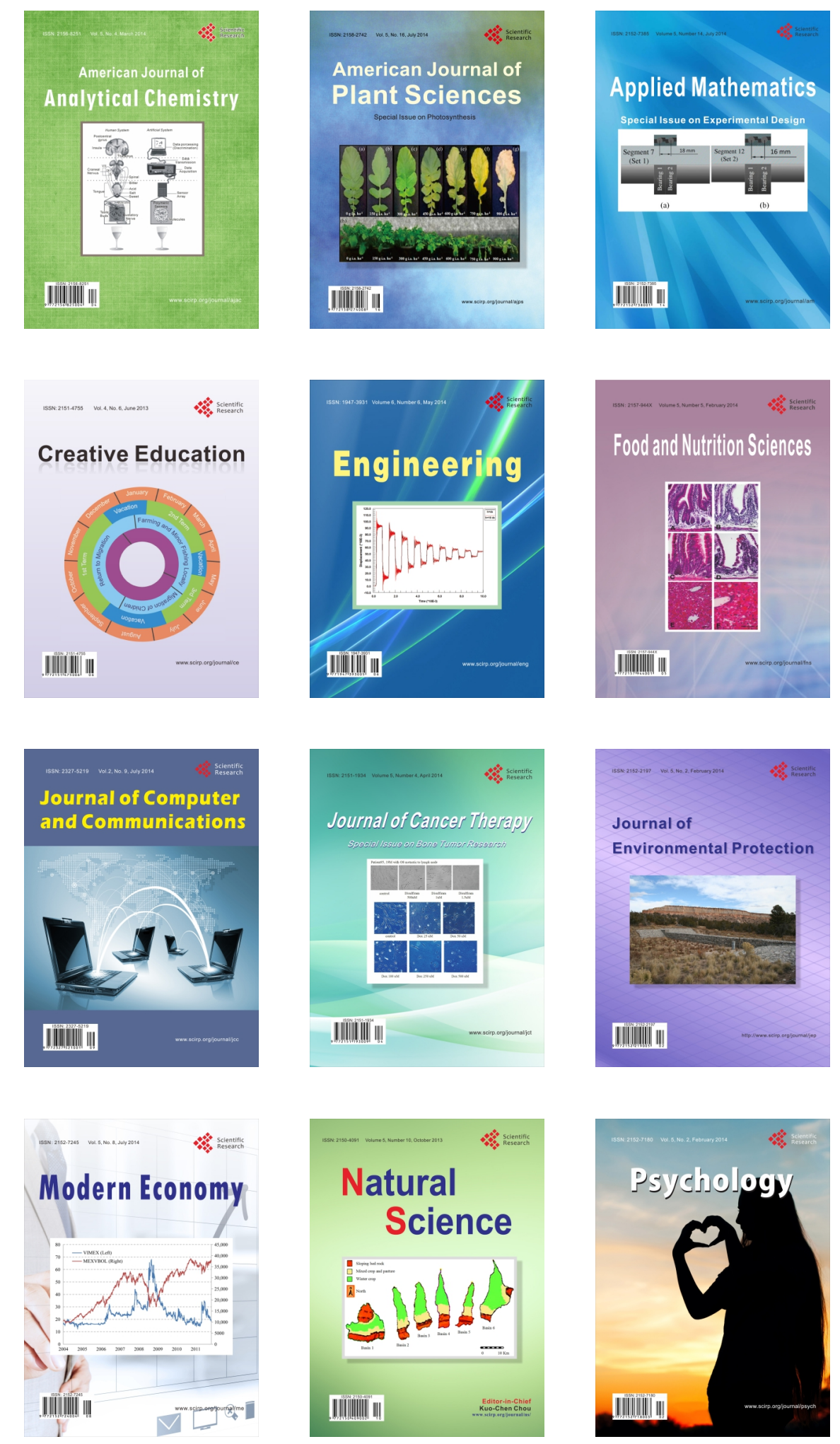